JPDN ISSN 2579-6461 (Online) ISSN 2460-6324 (Print)

Jurnal Pendidikan Dasar Nusantara

Volume $7 \mid$ Nomor 1 |Juli 2021|

DOI:https://doi.org/10.29407/jpdn.v7i1.16170

\title{
PENERAPAN M-LEARNING BERBASIS EDMODO UNTUK MENINGKATKAN HASIL BELAJAR IPS KELAS V SDN SRIWEDARI NO. 197 SURAKARTA
}

\author{
Aan Budi Santoso', Ninda Beny Asfuri ${ }^{2}$ \\ aan.budi2@gmail.com ${ }^{1}$,nindaarjuna@gmail.com ${ }^{2}$ \\ PGSD, FKIP, Universitas Tunas Pembangunan Surakarta ${ }^{1,2}$
}

\begin{abstract}
Abstrak: Tujuan penelitian ini adalah meningkatkan hasil belajar IPS dikelas V SD Negeri Sriwedari No. 197 Surakarta dengan menggunakan media m-learning berbasis edmodo.Pelaksanaan penelitian bertempat di SD Negeri Sriwedari No. 197 Surakarta. Sasaran penelitian ini adalah siswa kelas V tahun ajaran 2020 / 2021 yang berjumlah 26 siswa. Mekanisme penelitian tindakan kelas ini berlangsung 2 siklus dengan satu kali pertemuan, disetiap siklus ada 4 tahapan yaitu perencanaan, tindakan, observasi dan refleksi. Pengumpulan data yang digunakan yaitu tes dan non tes ( obeservasi dan dokumentasi). Validasi yang digunakan dengan 3 metode yaitu tes, observasi, dan dokumentasi. Teknik analisis data pada penelitian ini menggunakan statistik sederhana.Berdasarkan pelaksanaan prasiklus pada mata pelajaran IPS dengan materi menghargai jasa dan peran tokoh perjuangan dalam mempersiapkan kemerdekaan Indonesia dengan menggunakan media m-learning berbasis edmodo belum berhasil dilihat dari 26 siswa hanya 4 siswa yang tuntas KKM sehingga presentase ketuntasaannya mencapai 15,38\% dengan nilai rata - rata 51,51. Pada siklus 1 berhasil mengalami penurunan presentase ketuntasan yaitu $11,84 \%$ akan tetapi nilai rata - rata mengalami peningkatan yaitu 55,35. Siklus 2 mengalami peningkatan dari 26 siswa hanya 5 siswa atau 19,23\% yang tidak mencapai ketuntasan, dan 21 siswa atau 80,76\% mencapai ketuntasan sesuai dengan KKM yaitu 70.Dengan demikian, penggunaan media m-learning berbasis edmodo tepat diterapkan dalam pembelajaran IPS khususnya materi menghargai jasa dan peran tokoh perjuangan dalam mempersiapkan kemerdekaan Indonesia yang berdampak pada peningkatkan aktivitas guru, aktivitas siswa, dan hasil belajar siswa kelas V SD Negeri Sriwedari No. 197 Surakarta.
\end{abstract}

Kata kunci: hasil belajar IPS, m-learning berbasis edmodo.

\section{IMPLEMENTATION OF M-LEARNING BASED ON EDMODO TO INCREASE LEARNING OUTCOMES FOR IPS CLASS V SD N SRIWEDARI NO. 197 SURAKARTA}


Aan, Ninda. Penerapan M-Learning Berbasis Edmodo...

Abstract: The purpose of this study is to improve social studies learning outcomes in class V SD Negeri Sriwedari No. 197 Surakarta by using edmodo-based m-learning media.The research was held at SD Negeri Sriwedari No.197 Surakarta. The target of this study was the fifth grade students of the 2018/2019 academic year, which amounted to 26 students. The classroom action research mechanism takes place in 2 cycles with one meeting, in each cycle there are 4 stages, namely planning, action, observation and reflection. Data collection used is test and non-test (observation and documentation). Validation is used with 3 methods, namely test, observation, and documentation. The data analysis technique in this study uses simple statistics.Based on the implementation of the pre-cycle on social studies subjects with material appreciating the services and role of the figure of struggle in preparing for Indonesian independence by using edmodo-based m-learning media not yet seen from 26 students only 4 students who completed KKM so that the percentage reached $15.38 \%$ with average scores - average 51.51. In cycle 1, the percentage of completeness was successful, which was $11.84 \%$ but the average value increased by 55.35. Cycle 2 experienced an increase of 26 students, only 5 students or $19.23 \%$ who did not achieve completeness, and 21 students or $80.76 \%$ achieved completeness according to KKM, namely 70.Thus, the use of edmodo-based mlearning media is appropriately applied in social studies learning especially material that appreciates the services and role of the struggle figure in preparing for Indonesian independence which has an impact on increasing teacher activities, student activities, and learning outcomes of class V SD Negeri Sriwedari No. 197 Surakarta .

Keywords: IPS, m-learning based edmodo learning outcomes.

\section{PENDAHULUAN}

Semua manusia hidup di dunia pastinya memerlukan pendidikan di dalam kehidupannya dimulai dari yang masih kanak-kanak sampai yang sudah dewasa. Dengan pendidikan manusia dapat mengembangkan potensi dirinya sehingga menjadi manusia yang berkwalitas dan berpendidikan untuk menentukan tujuan hidupnya di masa depan.

Peran lembaga pendidikan yang sering disebut dengan sekolah menjadi sangat penting. Begitu pula peran dari guru sebagai pendidik merupakan salah satu faktor penentu keberhasilan pendidikan di samping faktor dari keluarga dan lingkungannya. Keberhasilan pendidikan dimulai dari proses belajar mengajar yang sukses. Di dalam kesuksesan pendidikan, seorang guru dituntut untuk dapat meningkatkan aktivitas dan hasil belajar siswa terutama untuk mata pelajaran tertentu yang tidak diminati oleh siswa yaitu salah satunya adalah Ilmu Pengetahuan Sosial (IPS). 
Aan, Ninda. Penerapan M-Learning Berbasis Edmodo...

Dalam hal pembelajaran IPS, kebanyakan siswa menganggap IPS adalah pelajaran yang sulit, tidak menarik dan membosankan. Selain itu minimnya media disuatu lembaga juga menyebabkan pembelajaran hanya menggunakan metode cerama, sehingga siswa sulit memahami penjelasan dari guru hal ini terbukti pada siswa kelas IV di SD Negeri Sriwedari No.197 masih belum memperoleh hasil yang maksimal.

Permasalahan mata pelajaran Ilmu Pengetahuan Sosial tersebut juga masih terjadi di Sekolah Dasar khususnya di Kota Surakarta. Berdasarkan hasil penelitian awal yang telah dilakukan oleh peneliti di SD Negeri SriwedariNo.197 Surakarta, didapatkan beberapa permasalahan tentang hasil belajar siswa. Dari penelitian tersebut ditemukan nilai rata-rata kelas paling rendah yaitu kelas V pada mata pelajaran Ilmu Pengetahuan Sosial. Mata pelajaran IPS mempunyai nilai rata-rata paling rendah dibandingkan dengan mata pelajaran lain. Hasil belajar ini memiliki rata-rata rendah yaitu 53,46 juga ditunjukkan dengan data dari 26 siswa ada 15 siswa $(58,53 \%)$ yang mendapatkan nilai dibawah Kriteria Ketuntasan Minimal (KKM) yaitu 70, sedangkan sisanya 11 siswa $(41,46 \%)$ nilainya diatas KKM.

Berdasarkan observasi kelas V di SD Negeri Sriwedari No. 197, dapat diketahui permasalahan dalam pelaksanaan pembelajaran yaitu rendahnya hasil belajar IPS, siswa tidak terlibat aktif selama pembelajaran, minimnya media menjadikan pembelajaran hanya menggunakan metode ceramah saja, proses pembelajaran yang masih cenderung kurang memberikan peluang kepada siswa untuk aktif mengemukakan pendapatnya, kurang aktifnya siswa dalam proses pembelajaran dikelas bisa dilihat saat guru memberikan pertanyaan hanya satu atau dua siswa saja yang berani menjawab pertanyaan, kurangnya minat siswa dalam mengikuti pembelajaran IPS bisa tampak saat pembelajaran berlangsung ada siswa yang tidak memperhatikan gurunya yang sedang mengajar seperti bermain, asyik dengan dirinya sendiri, dan sebagainya, sehingga berdampak pada nilai akhir atau hasil belajar.

Mobile learning merupakan model pembelajaran yang memanfaatkan teknologi informasi dan komunikasi. Dengan demikian, mobile learning bermanfaat saat menyediakan materi ajar yang dapat diakses setiap saat dengan visualisasi yang menarik. Majid (2016) menyatakan bahwa pengembangan mobile learning bertujuan agar proses belajar dapat berjalan sepanjang waktu (long life learning), siswa dapat lebih aktif dalam proses pembelajaran dan menghemat waktu, sebab siswa dapat mengumpulkan tugasnya 
Aan, Ninda. Penerapan M-Learning Berbasis Edmodo... tanpa dia harus hadir di kelas. Selain itu mobile learning juga dapat meningkatkan kualitas belajar mandiri. M-learning atau mobile learning sering didefinisikan sebagai $e$ learning yaitu media melalui perangkat komputasi mobile (Andy,2007:6). Ally (2004) mendefinisikan mobile learning merupakan penyampaian bahan pembelajaran elektronik pada alat komputasi mobile agar dapat diakses dari mana saja dan kapansaja.

Menurut Rismayanti (2012:1) edmodo adalah platform media sosial yang sering digambarkan menyerupai facebook untuk sekolah dan dapat berfungsi lebih banyak lagi sesuai dengan kebutuhan. Edmodo yang dikenal memiliki tampilan dan fitur menyerupai facebook dirancang sedemikain rupa oleh pendidik guna menciptakan platform atau media pembelajaran berbasis internet secara aman dan nyaman yang bisa digunakan oleh guru dan siswa. Edmodo adalah jaringan sosial pribadi bagi guru dan siswa dengan platform sosial yang aman, dengan model kicauan seperti situs jejaring sosial pada umumnya edmodo dapat menjadikan jaringan khusus bagi guru dan siswa untuk berbagi ide, berkas, peristiwa, dan tugas menurut Shelly (2011:6-54). Sedangkan menurut Wankel (2011:24), edmodo adalah jejaring sosial dan layanan micro blogging yang di desain khusus untuk dunia pendidikan yang dapat dioprasikan seperti layaknya Twitter, dengan membatasi jalan aksesruang khusus atau grup, guru dan siswa dapat saling mengirim catatan, link, berkas, pengumuman, tugas dan bertukan informasi dilingkungan yang aman. Jadi dapat disimpulkan dari pendapat diatas bahwa edmodo merupakan media berunsurkan pendidikan dimana pemanfaatannya bergunauntuk mengirim materi pelajaran, mengirim tugas, menulis pengumuman bahkan juga bisa dijadikan alat diskusi untuk tukar pendapat antara guru dan siswa.

Literasi yang minim dimiliki oleh siswa SD Negeri Sriwedari No.197 Surakarta mengakibatkan rendahnya hasil belajar serta kurangnya kemampuan bertanya khususnya dalam mata pelajaran IPS materi menghargai jasa dan peran tokoh perjuangan dalam mempersiapkan kemerdekaan Indonesia, sehingga guru harus memiliki cara untuk menarik perhatian siswa supaya gemar membaca sebagai penunjang pembelajaran. Salah satu cara yang bisa dilakukan adalah dengan optimalisasi penggunaan media internet. SD Negeri Sriwedari No.197 Surakarta memiliki akses internet yang jarang di optimalkan penggunaannya melalui leptop atau komputer dari pihak sekolah maupun peneliti, sehingga hal ini bisa menjadi salah satu alternatif guru untuk mengembangkan referensi melalui internet. 


\section{Aan, Ninda. Penerapan M-Learning Berbasis Edmodo...}

Selain itu melalui internet siswa akan lebih tertarik untuk mempelajari hal-hal yang baru untuk mereka. Sebab melalui teknologi ini siswa bisa mengakses referensi kapanpun dan dimanapun sesuai dengan keinginan mereka. Peneliti menawarkan aplikasi edmodo sebagai salah satu aplikasi yang dapat meningkatkan semangat siswa kelas V SD Negeri Sriwedari No.197 Surakarta dalam meningkatkan kemampuan literasi mereka. Hal ini disebabkan edmodo adalah aplikasi yang menarik dan mudah digunakan serta mampu membuat perencanaan pembelajaran sehingga siswa merasa bahwa kegiatan yang dilakukan oleh dirinya adalah kegiatan yang mengasyikkan dan tidak membosankan. Melalui edmodo, guru dapat membagi siswa ke dalam kelompok kecil dan mulai membangun diskusi dengan siswa, diskusi ini dimaksudkan agar siswa aktif melakukan interaksi pada teman dan gurunya, serta untuk meningkatkan kemampuan mereka dalam bertanya.

Tujuan penelitian dalam artikel ini adalah untuk meningkatkan hasil belajar dalam mata pelajaran IPS dengan menerapkan m-learning berbasis edmodo di SD Negeri Sriwedari No.197 Surakarta karena dengan penggunaan edmodo dalam pembelajaran memungkinkan guru akan lebih mudah dalam memonitor aktivitas siswa dalam edmodo learning environment. Tidak ada yang bisa memasuki fitur tersebut tanpa persetujuan dari guru yang bersangkutan. Izin dari guru mutlak diperlukan apabila ada siswa yang ingin menggunakan fitur tersebut. Tidak ada yang bisa masuk ke dalam edmodo tanpa adanya undangan untuk masuk, tidak seperti facebook yang pada dasarnya bisa memasukkan siapa saja ke dalam grup diskusi. Dengan adanya fitur tersebut, guru dapat meminimalisir adanya penyalahgunaan serta penyusup yang ada di dalam Platform edmodotersebut.

\section{METODE}

Jenis penelitian yang dilaksanakan oleh peneliti adalah jenis Penelitian Tindakan Kelas (PTK). Pada prinsipnya jenis Penelitian Tindakan Kelas (PTK) merupakan penelitian terhadap siswa dari segi interaksi dalam proses pembelajaran yang dilakukan untuk memperbaiki teknik pembelajaran, metode pembelajaran, dan pemberian materi pembelajaran dengan tujuanuntuk meningkatkan hasil belajar siswa. Dengan Penelitian Tindakan Kelas, guru dapat merefleksi dan mengevaluasi diri, apakah guru sudah melaksanakan tugas utamanya secara professional sebagai 
Aan, Ninda. Penerapan M-Learning Berbasis Edmodo... pengajar serta dapat menemukan solusi atas permasalahan-permasalahan yang muncul dalam praktek-praktekpembelajaran.

Subyek dalam penelitian ini terdiri dari siswa dan guru. Siswa yang menjadi subjek dalam penelitian ini adalah siswa kelas V SD Negeri Sriwedari No.197 Surakarta pada tahun ajaran 2018/2019. Banyaknya siswa yang menjadi subjek penelitian adalah 26 siswa, terdiri dari 17 siswa laki-laki dan 9 siswa perempuan. Siswa menjadi penelitian pada saat pengumpulan informasi dan saat testing.Guru yang menjadi subjek dalam penelitian ini adalah guru kelas V SD Negeri Sriwedari No.197 Surakarta pada tahun ajaran 2020/2021. Guru berperan sebagai subjek penelitian karena guru berperan dalam pengumpulaninformasi dan melaksanakan pembelajaran IPS menggunakan produk mediam-learningberbasis edmodo yang telah dibuat oleh peneliti.

Penelitian ini dilaksanakan melalui kerja kolaborasi antara guru kelas V SD Negeri Sriwedari No.197 Surakarta dengan peneliti. Dalam proses Penelitian Tindakan Kelas terdiri dari beberapa siklus dan setiap siklus terdiri dari beberapa tahap atau komponen yang harus dilakukan. Tindakan yang diberikan adalah proses pembelajaran dengan menerapkan m-learning berbasis edmodo yang dibagidalam dua siklus dengan empat tahapan, yaitu (1) perencanaan tindakan, (2) pelaksanaan tindakan, (3) observasi dan evaluasi dan (4) refleksi.

Pengumpulan data pada penelitiab PTK ini menggunakan beberapa teknik pengumpulan data dan alat pengumpulan data, teknik yang digunakan yaitu (1) Wawancaa, (2) Observasi, (3) Tes, dan (4) Dokumentasi dengan menggunakan alat pengumpulan data (1) Lembar Wawancara, (2) Lembar Observasi, (3) LembarTes. Untuk menguji kevalidan data Penelitian tindakan kelas ini menggunakan triangulasi sumber yaitu dengan membandingkan dan mengecek balik derajat kepercayaan suatu informasi yangdiperoleh melalui waktu dan alat yang berbeda, yaitu pengamatan dari proses pembelajaran, tes unjuk kerja siswa, silabus, RPP, hasil wawancara tentang pembelajaranIPS. 
Aan, Ninda. Penerapan M-Learning Berbasis Edmodo...

HASIL

Tabel 1. Aktivitas guru pada siklus 2

\begin{tabular}{|c|c|c|c|c|c|}
\hline \multirow[b]{2}{*}{ NO } & \multirow[b]{2}{*}{ ASPEK YANG DIAMATI } & \multicolumn{4}{|c|}{ KRITERIA NILAI } \\
\hline & & 4 & 3 & 2 & 1 \\
\hline 1. & Melakukan apersepsi & $\sqrt{ }$ & & & \\
\hline 2. & Menjelaskan tujuan pembelajaran & $\sqrt{ }$ & & & \\
\hline 3. & Mempersiapkan sumber & $\sqrt{ }$ & & & \\
\hline 4. & Membentuk kelompok belajar & $\sqrt{ }$ & & & \\
\hline 5. & Membagi lembar kegiatan siswa & $\sqrt{ }$ & & & \\
\hline 6. & $\begin{array}{l}\text { Memperhatikan dan membimbing siswa dalam } \\
\text { kelompok }\end{array}$ & $\sqrt{ }$ & & & \\
\hline 7. & $\begin{array}{l}\text { Memperhatikan dan membimbing siswa dalam } \\
\text { mengerjakan soal }\end{array}$ & $\sqrt{ }$ & & & \\
\hline 8. & $\begin{array}{l}\text { Meningkatkan kembali kepada tiap-tiap kelompok } \\
\text { untuk mempresentasikan hasil kegiatan kelompok } \\
\text { didepan kelas }\end{array}$ & & $\sqrt{ }$ & & \\
\hline 9. & $\begin{array}{l}\text { Memberikan kuis kepada setiap siswa dalam } \\
\text { kelompok }\end{array}$ & $\sqrt{ }$ & & & \\
\hline 10. & $\begin{array}{l}\text { Memberikan pembahasan evaluasi terhadap kerja } \\
\text { kelompok }\end{array}$ & & $\sqrt{ }$ & & \\
\hline 11. & Memeriksa hasil tes & $\sqrt{ }$ & & & \\
\hline 12. & Memberikan penghargaan kepada kelompok belajar & $\sqrt{ }$ & & & \\
\hline 13. & Guru mengadakan refleksi & $\sqrt{ }$ & & & \\
\hline 14. & $\begin{array}{l}\text { Guru mengadakan tindak lanjut hasil individu dan } \\
\text { bertanya terkait materi }\end{array}$ & $\sqrt{ }$ & & & \\
\hline 15. & $\begin{array}{l}\text { Guru bersama siswa menyimpulkan materi yang } \\
\text { telah diajarkan }\end{array}$ & & $\sqrt{ }$ & & \\
\hline & Jumlah & & & & \\
\hline & Presentase & & & & \\
\hline & Keterangan & & & Baik & \\
\hline
\end{tabular}

Sumber: Data penelitian 
Aan, Ninda. Penerapan M-Learning Berbasis Edmodo...

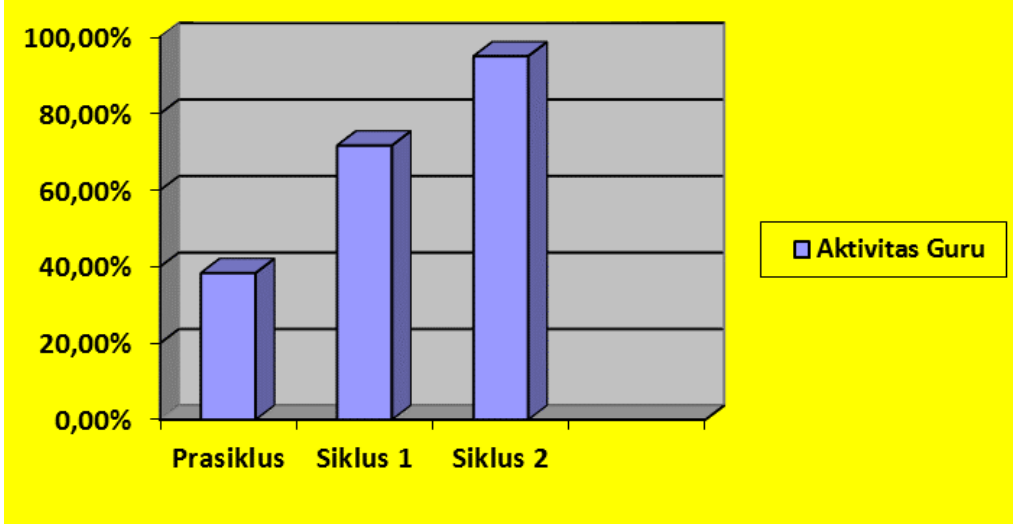

Sumber: olah data penelitiaan

Gambar 1. Diagram perbandingan aktivitas Guru tiap siklus

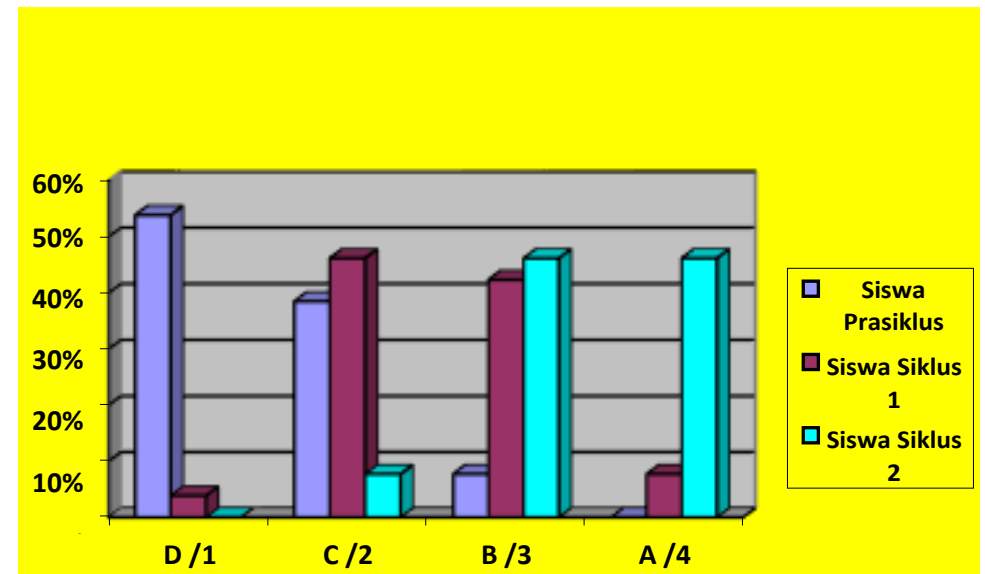

Gambar 2. Diagram perbandingan aktivitas siswa tiap siklus 
Aan, Ninda. Penerapan M-Learning Berbasis Edmodo...

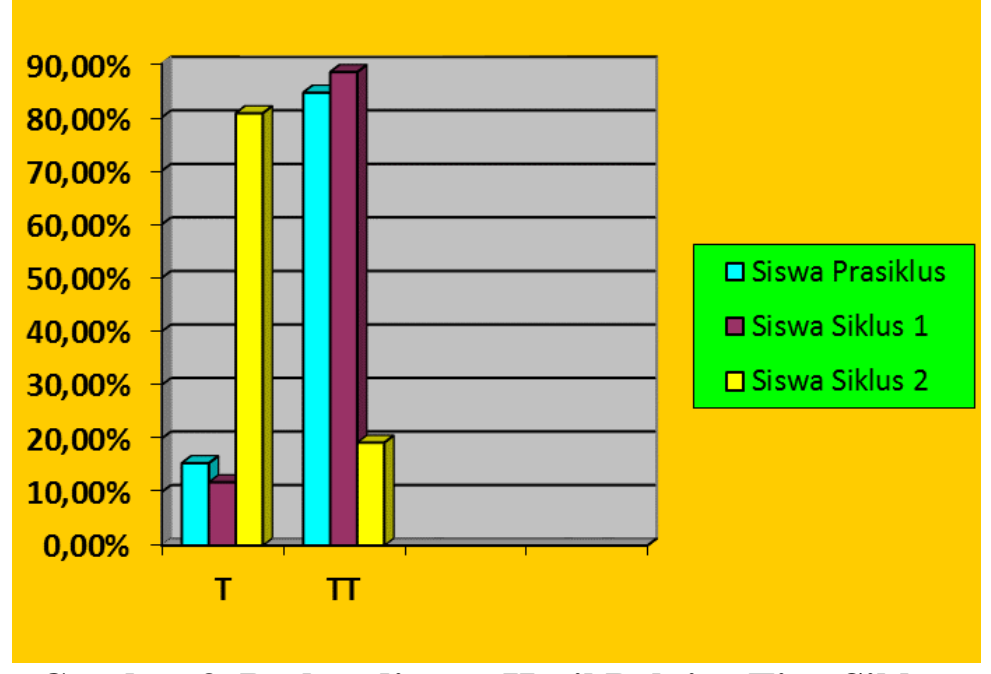

Gambar 3. Perbandingan Hasil Belajar Tiap Siklus

\section{PEMBAHASAN}

\section{A. PRA SIKLUS}

Dari hasil observasi awal ditemukan data aktifitas guru sebagai berikut: Dalam menyajikan bahan ajar dalam mata pelajaran IPS guru sering menggunakan metode ceramah. Kegiatan berpusat pada aktifitas guru, komunikasi hanya satu arah yaitu dari guru ke siswa, jarang memberi kesempatan bertanya kepada siswa, serta tidak ada kegiatan kerjasama siswa dalam melakukan kegiatan kelas.Berdasarkan Gambar 1 diatas dinyatakan bahwa aktivitas guru pada waktu pembelajaran diprasiklus, presentase guru menunjukan $38,33 \%$ yang artinya pembelajaran cukup baik.

Dari hasil observasi awal ditemukan data aktivitas siswa sebagai berikut: Oleh karenanya guru menerapkan metode ceramah dalam penyajian materi ajar akibatnya siswa pasif dalam aktivitas belajar. Siswa hanya duduk mendengarkan penjelasan guru, tidak ada kegiatan kerjasama dan kurangnya kegiatan, sehingga siswa cenderung berbicara sendiri-sendiri dan bosan.

Berdasarkan tabel data aktivitas siswa prasiklus yang dilaksanakan pada saat pembelajaran berlangsung dengan metode ceramah, siswa kebanyakan hanya memperhatikan dan mendengarkan saja. Terlihat dari jumlah presentasinya yaitu $53,84 \%$ dengan jumlah 14 siswa. Sedangkan yang aktif hanya 2 siswa dengan 
Aan, Ninda. Penerapan M-Learning Berbasis Edmodo... presentase $7,69 \%$ dan yang kadang - kadang aktif hanya 10 orang siswa dengan presentase $38,46 \%$.

Siswa yang mencapai ketuntasan belajar pada pra siklus hanya 4 siswa dengan presentasi 15,38\% hal ini berarti ada 22 siswa dengan presentasi 84,62\% yang belum mencapai ketuntasan belajar. Dari data aktivitas guru dan siswa serta hasil belajar siswa menunjukkan bahwa pola pembelajaran yang diterapkan guru kurang baik dan perlu diperbaiki, melalui Penelitian Tindakan Kelas dengan menerapkan m-learning berbasis edmodo untuk meningkatkan hasil belajar IPS.

\section{B. SIKLUS 1}

Berdasarkan data penelitian pada siklus 1 menunjukkan bahwa sebagaian aspek penelitian guru sudah mencapai target yaitu aspek memotivasi siswa, aspek membimbing diskusi kelompok, aspek membimbing pengisian LKS pada edmodo, aspek memberi penghargaan pada kelompok, aspek memberi evaluasi, serta sebagian aspek yang lainnya belum mencapai target yang ditentukan (80\%), namun guru menyampaikan pembelajaran dengan sangat baik dan persentase keberhasilan sebesar 71,66\%, hal itu presentase aktivitas guru meningkat.

Berdasarkan pengamatan dari observer siklus 1pada tabel diatas ditemukan bahwa sebagian besar siswa cenderung aktif atau kadang-kadang aktif dilihat presentasenya yaitu 46,15\% dengan jumlah 12 siswa. Akan tetapi siswa yang aktif mengalami peningkatan, diprasiklus hanya 2 siswa yang aktif, disiklus 1 ada 11 siswa yang aktif dengan presentase $42,3 \% \%$ dan terdapat siswa yang slalu aktif yaitu 2 orang siswa dengan presentase 7,69\%. Namun masih terdapat siswa yang pasif yaitu 1 siswa dengan presentase 3,84\%.Hal ini berarti aktivitas siswa belum mencapai yang diharapkan. Peneliti mengharapkan agar aktivitas siswa banyak yang selalu aktif, memperhatikan, medengarkan, dan berani bertanya sehingga kegiatan aktivitas siswa bisa mempengaruhi hasil belajarnya.

Berdasarkan Tabel diatas, skor ulangan atau evaluasi yang dicapai siswa adalah 11,84\% siswa yang tuntas atau lulus KKM ( Kriteria Ketuntasan Minimal yaitu sebanyak 3 siswa saja, hal ini mengalami penurunan 3,54\% dengan jumlah 1

siswa. Setelah melihat aktivitas siswa, penurunan ini tidaklah mengagetkan 
Aan, Ninda. Penerapan M-Learning Berbasis Edmodo...

dikarnakan siswa menemukan sesuatu yang baru buat diri siswa,jadisiswa tidak terfokus dengan materi yang diajarkan melainkan terfokus dengan media yang dikenalkan oleh guru atau peneliti.

Sedangkan jumlah siswa yang tidak memenuhi adalah sebanyak 23 siswa atau $88,46 \%$. Akan tetapi, perolehan nilai setiap siswa mengalami peningkatan dari prasiklus dengan rata-rata nilai perolehan sebesar 45,09 ke siklus 1 dengan perolehan nilai rata-rata sebesar 52,44. Ketuntasan klasikal pembelajaran siklus I belum tercapai karena kurang dari $80 \%$ siswa yang mencapai KKM. Dengan memperhatikan hasil evaluasi pada siklus I, maka peneliti melanjutkan penelitian tindakan pada siklus II mengingat masih adanya nilai yang belum tuntas dan ada poin kinerja guru yang belum terpenuhi.

Selain merangkum hasil observasi aktivitas guru, siswa, dan hasil belajar, pada tahap ini guru juga melakukan evaluasi tentang pelaksanaan pembelajaran menggunakan media m-learning berbasis edmodo pada siklus I dengan observasi untuk memperbaiki kekurangan dan mengatasi hambatan yang dihadapi oleh peneliti dan siswa selama proses pembelajaran.

\section{SIKLUS 2}

Berdasarkan data penelitian pada siklus 2 menunjukkan bahwa semua aspek penilaian guru sudah mencapai target. Guru menyampaikan pembelajaran dengan kemampuan maksimal dan sangat baik, mendapatkan kenaikan persentase keberhasilan dari siklus 1 kesiklus 2 sebesar $95 \%$. Hal itu sudah melebihi target yang ditentukan yaitu $80 \%$.

Berdasarkan pengamatan dari observer pada siklus 2, aktivitas siswa mengalami peningkatan. Sebagian besar siswa selalu aktif, memperhatikan, mendengarkan dan bertanya. Saat siswa bekerja sama dengan kelompoknya, sebagian besar siswa aktif dalam berdiskusi menentukan jawabannya, bahkan siswa yang kemarin aktif dan mendapat nilai baik justru hanya seperti pendamping bagi siswa yang lain, siswa yang kemarin baik seperti penentu bagi teman - teman yang lain ketika ada jawaban yang berbeda. Hal ini berarti aktivitas siswa sudah mencapai yang diharapkan. Peneliti mengharapkan aktivitas siswa banyak yang selalu aktif, memperhatikan, medengarkan, dan berani bertanya tetap dipertahankan 
Aan, Ninda. Penerapan M-Learning Berbasis Edmodo...

ketika pelajaran yang lain sehingga kegiatan aktivitas siswa bisa mempengaruhi hasil belajar yang lebih baik.

Berdasarkan tabel diatas skor rata-rata hasil ulangan yang dicapai siswa adalah $80,76 \%$. Dan telah terjadi peningkatan nilai rata-rata sebesar $68,92 \%$ dari pada nilai ulangan pada siklus I. Sedangkan jumlah siswa yang memenuhi KKM (Kriteria Ketuntasan Minimal) adalah sebanyak 21 siswa $(80,76 \%)$ sedang yang belum menuhi KKM (Kriteria Ketuntasan Minimal) sebesar 5 siswa (19,23\%). Ketuntasan pada siklus 2 ini sudah tercapai karena lebih dari $80 \%$ siswa yang mencapai KKM (Kriteria Ketuntasan Minimal).

\section{SIMPULAN}

Simpulan berisikan substansi pemaknaan tentang tujuan yang dielaborasikan dengan hasil dan pembahasan, sehingga ada keterkaitan/simpulan. Bagian ini juga dapat ditambah tentang tindak lanjut hasil penelitian kedepannya.

Kesimpulan berdasarkan hasil penelitian tindakan kelas dalam penerapan mlearning berbasis edmodo untuk meningkatkan hasil belajar IPS materi menghargai jasa dan peran tokoh perjuangan dalam mempersiapkan kemerdekaan Indonesia kelas V SD Negeri Sriwedari No. 197 Surakarta adalah sebagai berikut.

\section{A. Peningkatan Aktivitas Guru}

Hasil nilai rata - rata aktivitas guru pada prasiklus sebesar 38,33\% dengan kriteria cukup baik. Setelah melakukan tindakan dengan menerapkan media mlearning berbasis edmodo pada siklus I nilai rata-rata aktivitas guru mengalami peningkatan sebesar 71,66\% dengan kriteria baik dan meningkat lagi pada siklus II menjadi 95\% dengan kriteria sangat baik. Aktivitas guru mengalami peningkatan sebesar 33,33\% dari prasiklus ke siklus I, dan mengalami peningkatan sebesar $56,67 \%$ dari pra siklus ke siklus II. Peningkatan hasil nilai rata-rata tersebut membuktikan bahwa dengan menerapkan media m-learning berbasis edmodo dapat memotivasi aktivitas guru, sehingga dapat meningkatkan aktivitas guru dalam proses pembelajaran.

\section{B. Aktivitas Belajar Siswa}

Akivitas siswa kelas V SD Negeri Sriwedari No. 197 Surakarta setelah melaksanakan pembelajaran menghargai jasa dan peran tokoh perjuangan dalam 
Aan, Ninda. Penerapan M-Learning Berbasis Edmodo... mempersiapkan kemerdekaan Indonesia dengan media m-learning berbasis edmodo mengalami perubahan ke arah positif. Peserta didik lebih aktif selama proses pembelajaran, lebih fokus dalam mendengarkan penjelasan guru tentang materi, lebih kondusif, lebih percaya diri untuk mengemukakan pendapat, serta lebih aktif bekerja sama dalamberdiskusi.

\section{Hasil BelajarSiswa}

Memahami materi menghargai jasa dan peran tokoh perjuangan dalam mempersiapkan kemerdekaan Indonesia sudah mengalami peningkatan, mulaidari prasiklus yang belum memahami sampai dengan siklus 2 yang sudah memahami menggunakan media m-learning berbasis edmodo mengalami peningkatan. Nilai rata-rata yang dicapai peserta didik pada prasiklus sebesar 51,51 dan presentasenya $15,38 \%$ berada kurang baik. Pada siklus I, nilai rata- rata peserta didik mengalami peningkatan sebesar 3,84. Tetapi presentase ketuntasannya menurun sebesar 3,54\% $\%$, nilai rata - ratanya menjadi 55,35 presentasenya menjadi $11,84 \%$ dan masih berada dalam kategori cukup baik. Nilai rata-rata pada siklus I belum mencapai batas ketuntasan yang telah ditetapkan sehingga dilakukan siklus II. Setelah dilaksanakan tindakan siklus II, nilai rata-rata peserta didik mengalami peningkatan sebesar 24,36 atau sebesar $68,92 \%$ menjadi 75,87 presentasenya $80,76 \%$ dan berada dalam kategori baik. Peningktan nilai rata-rata tersebut membuktikan keberhasilan pembelajaran menghargai jasa dan peran tokoh perjuangan dalam mempersiapkan kemerdekaan Indonesia dengan media m-learning berbasis edmodo berhasil.

Dengan demikian, penggunaan media m-learning berbasis edmodo tepat diterapkan dalam pembelajaran IPS khususnya materi menghargai jasa dan peran tokoh perjuangan dalam mempersiapkan kemerdekaan Indonesia yang berdampak pada peningkatkan aktivitas guru, aktivitas siswa, dan hasil belajar siswa kelas V SD Negeri Sriwedari No.197Surakarta.

\section{UCAPAN TERIMAKASIH}

Peneliti mengucapkan terima kasih kepada Direktorat Riset dan PengabdianMasyarakat, UTP Surakarta sebagai penyandang dana, terima kasih juga kepada SDNegeri Sriwedari No.197 Surakarta atas kerjasamanya dalam proses penelitian 
Aan, Ninda. Penerapan M-Learning Berbasis Edmodo...

\section{DAFTAR RUJUKAN}

Ally, M. 2004. Using Learning Theories to Design Instruction for Mobile Devices Procedings of the Mobile Learning 2004. Roma: International Conference.

Anggraeni, Desi. 2011. Peningkatan Kualitas Pembelajaran IPS Melalui Model Kooperatif Tipe Course Review Horay pada Siswa Kelas IV SD Negeri Sekaran 1 Semarang. Jurnal Kreatif Jurnal Kependidikan Dasar. Vol. 1 No. 12 Bulan Februari Tahun 2011.

Andy, Yonatan. 2007. Perancangan dan Implementasi Mobile Learning untuk Pembelajaran Bahasa Jepang Berbasis Brew. Bandung: STEI ITB.

Asyhar, Rayandra. 2012. Kreatif Mengembangkan Media Pembelajaran. Jakarta: Referensi Jakarta

B, Achmad Syaiful. 2014. Penggunaan Model Pembelajaran Tipe STAD untuk Meningkatkan Hasil Belajar Siswa Kelas V SDN Kadung Rejo, Waru. Jurnal PGSD Vol. 2 No. 2 Tahun 2014..

Daryanto. 2016. Media Pembelajaran Edisi ke-2. Yogyakarta: Gava Media.

Majid, Abdul. 2016. Pengembangan Mobile Learning untuk Meningkatkan Hasil Belajar Siswa. Jurnal Pengembangan Bahan Ajar Vol. 12 No. 26 Tahun 2016.

Musfiqon. 2012. Pengembangan Media dan Sumber Pembelajaran. Jakarta: Prestasi Pustaka Raya.

Priowiryanto, Gatot. 2013. Sumber Simulasi Digital Versi September 2013 Upaya Mengkomunikasikan Gagasan Melalui Presentasi Digital Southeas Asian Ministers Of Education O Regional Open Learning Centre (Seamol 2013). Diakses Januari 2021

Rismayanti, Anti. 2012. Mengenal Lebih Dekat Edmodo Sebagai Media E- Learningdan Kolaborasi. (Online). Tersedia http://download.smkn1majalengka.sch.id. (20 Januari2020).

Sagala, Syaiful. 2007. Konsep dan Makna Pembelajaran. Bandung: Alfabeta. 
Aan, Ninda. Penerapan M-Learning Berbasis Edmodo...

Sanjaya, Wina. 2012. Media Kumunikasi Pembelajaran. Jakarta: Kencana Prenada Media Grup.

Sardiman. 2010. Revitalisasi Peran IPS dalam Pembangunan Karakter Bangsa. Jurnal Cakrawala Pendidikan

Sugiyono. 2014. Statistika untuk Penelitian.Bandung:Alfabeta.

Tamimudin, Muh. 2016. Pengembangan Mobile Learning untuk Meningkatkan Hasil Belajar Siswa. Jurnal Pengembangan Bahan Ajar Vol.12 No. 26 Tahun 2016.

Vemaat, Shelly Cashman. 2011. Discovering Computers 'Menjelajah Dunia Komputer' Fundamental. Salemba. Infotek.

Wahyudin. 2010. Keefektifan Pembelajaran Berbantuan Multimedia Menggunakan Metode Inkuiri Terbimbing untuk Meningkatkan Minat dan Pemahaman Siswa.Jurnal Pendidikan Fisika Indonesia FMIPA Unnes Vol 6 Bulan Januari Tahun 2010.

Wati, Ega Rima. 2016. Ragam Media Pembelajaran. Yogyakarta:Kata Pena.

Winkel. 2011. Belajar dan Pembelajaran. Jakarta: PT. Raja Grafindo.

Susanto, Ahmad. 2016. Teori belajar dan Pembelajaran. Jakarta: Prenada Media group. 